\title{
Czy możliwa jest europejska kultura strategiczna? Analiza porównawcza narodowych strategii bezpieczeństwa (Niemcy, Francja, Wielka Brytania)
}

Europejska finalité w dziedzinie bezpieczeństwa zakłada osiagnięcie „wspólnej obrony" wyposażonej w zintegrowane struktury kierujące siłami wojskowymi przeprowadzającymi operacje zarówno lekkiego, jak i ciężkiego kalibru. Oczywiście skuteczna obrona jest potrzebna nie tylko ze względu na wyzwania i zagrożenia dla UE. Może służyć także do wzmocnienia jej pozycji międzynarodowej, a nawet - paradoksalnie - pomóc ożywić stosunki transatlantyckie zgodnie z pozimnowojennym amerykańskim dezyderatem wprowadzenia nowego podziału ciężarów w zachodnim aliansie pomiędzy USA i Europę. Tak oto wygląda obiegowe, a zarazem wyidealizowane mniemanie na temat roli UE w dziedzinie bezpieczeństwa międzynarodowego ${ }^{1}$. Faktycznie ambicje UE są skromniejsze, a wspólna obrona pozostaje na razie polityczną wizją, która może nie doczekać się spełnienia. Pomysły zbudowania europejskiej armii, nuklearyzacji obrony czy nawet wspólnej obrony antyrakietowej są dość trudne do realizacji. ESDP koncentruje się na osiągnięciu zdolności do prowadzenia antykryzysowych misji w myśl stosownych unijnych zaleceń (Civilian Headline Goal 2008 i Military Headline Goal 2010). Można założyć, że skuteczne unijne zarządzanie kryzysami jest niezbędnym pierwszym krokiem do dalszego zacieśniania integracji europejskiej w dziedzinie bezpieczeństwa. Świadczą o tym operacje wojskowe UE jak i stworzenie poza ramami traktatowymi tzw. grup bojowych (Battle Groups), które jak dotąd nie zostały użyte, oraz jednocześnie obok nich budowa Europejskich Sił Szybkiego Reagowania (European Rapid Reaction Forces). Wielonarodowe oddziały dowodzone przez wielonarodowe struktury dowodzenia wyposażone we wspólnie rozwijane systemy uzbrojenia z pewnością będą sprzyjać kształtowaniu się europejskiej obrony. Można by w związku z tym domniemywać, że procesy takie poprzez socjalizowanie się elit wojskowych i politycznych będą sprzyjać unifikowaniu narodowych kultur strategicznych państw członkowskich. Z drugiej strony należy spodziewać się, że wpływ ten jednak będzie ograniczony, ponieważ w tej mierze różnice pomiędzy poszczególnymi państwami członkowskimi są po prostu spore i wydają się niełatwe do zniwelowania.

Europejska Strategia Bezpieczeństwa z grudnia 2003 r. rekomendowała jako niezbędny warunek powodzenia ESDP wytworzenie się europejskiej kultury strategicznej pośród państw członkowskich. Byłaby ona bowiem ważną przesłanką umożliwiającą

1 Krytycznie: K. Brunner, Europe's defence leadership: Why the Big Three won't be enough, „Europe's World” 2007; V. Perthes, Europäischer Lernprozess, „Handelsblatt” 3.02.2009; O. Osica, Armia europejska czy europejskie zdolności wojskowe?, „Komentarze natolińskie” 2007, nr 4 (14). 
podejmowanie skutecznych interwencji przez UE, wczesnych i „twardych”, i to jednocześnie w kilku miejscach, w razie potrzeby w ramach ,uprzedzającego zaangażowania”. Tylko takie zdecydowane przejmowanie przez UE odpowiedzialności miało nadać jej większy polityczny ciężar². Europejska Strategię Bezpieczeństwa trzeba też interpretować jako zachętę do wypracowania konsensualnego podejścia państw europejskich co do podstawowych priorytetów ESDP, a szerzej określenia, jaki charakter i pod jakimi warunkami UE winna angażować się w sferze bezpieczeństwa. Zalecenie to nawet jeśli wiązało się przede wszystkim z powszechnie aprobowaną koniecznością podnoszenia statusu międzynarodowego UE, wynikało, jak się wydaje, również z bardziej praktycznych względów. Europejska Strategia Bezpieczeństwa odnosiła się w ten sposób do narodowych tradycji w polityce zagranicznej i bezpieczeństwa, które rzutowały na rozbieżności w określaniu interesów bezpieczeństwa przez poszczególne państwa członkowskie. Tradycje te obejmowały nie tylko zróżnicowane nastawienie establishmentów politycznych wobec projekcji siły militarnej, związane z tym różnorakie praktyki w systemach ustrojowych, ale także olbrzymie wyczulenie liberalnych opinii publicznych w państwach europejskich na sprawy militarne. Należy więc postrzegać rekomendację Europejskiej Strategii Bezpieczeństwa w sprawie kształtowania europejskiej kultury strategicznej także jako wyraz troski o podstawowy deficyt polityczny przyszłych militarnych operacji wykonywanych przez UE, a mianowicie ich mniej czy bardziej pełną i nie kontrowersyjną polityczną legitymizację, która gwarantowałaby odpowiednie poparcie opinii publicznych w państwach członkowskich, a tym samym decydowałaby o ich sukcesie lub fiasku ${ }^{3}$.

W 5 lat po ogłoszeniu Strategii prezydencja francuska przedstawiła specjalny raport podsumowujący implementację jej zaleceń ${ }^{4}$. Nie wspomniano w nim o europejskiej kulturze strategicznej. Była tu jedynie mowa o dystynktywnym europejskim podejściu do polityki zagranicznej i bezpieczeństwa jako przesłance sukcesów misji antykryzysowych w poprzednich latach: „Posługując się niespotykanym gdzie indziej arsenałem instrumentów, UE już przyczynia się do zwiększenia bezpieczeństwa na świecie. Działaliśmy na rzecz budowy bezpieczeństwa ludzi przez ograniczanie ubóstwa i nierówności, wspieranie dobrych rządów i praw człowieka, pomoc rozwojową oraz elimi-

2 ,We need to develop a strategic culture that fosters early, rapid, and when necessary, robust intervention. As a Union of 25 members, spending more than 160 billion Euros on defence, we should be able to sustain several operations simultaneously. We could add particular value by developing operations involving both military and civilian capabilities. [...] Preventive engagement can avoid more serious problems in the future. A European Union which takes greater responsibility and which is more active will be one which carries greater political weight." „A Secure Europe in a better world. European Security Strategy”, Brussels, 12 December 2003.

${ }^{3}$ Sprawa europejskiej kultury strategicznej nurtuje również środowiska naukowe, czego przykładem jest wiele studiów koncepcyjnych przygotowanych przez prominentnych autorów. Zob. np. A. Hyde-Price, European Security, Strategic Culture, and the Use of Force, „European Security” 2004, vol. 13 (4); J. H. Matlary, When Soft Power Turns Hard: Is an EU Strategic Culture Possible?, „Security Dialogue” 2006, vol. 37 (1); A Strategic Culture for Europe, „Oxford Journal on Good Governance", vol. 2, No. 1, March 2005.

${ }^{4}$ Report by the EU High Representative Javier Solana, in association with the European Commission on the Implementation of the European Security Strategy, „Providing Security in a Changing World", S407/08, Brussels, 11 December 2008. 
nowanie pierwotnych przyczyn konfliktu i braku bezpieczeństwa. UE jest w dalszym ciągu największym darczyńcą dla krajów będących w potrzebie. Aby osiągnąć trwałą stabilizację potrzebne jest długoterminowe zaangażowanie".

Podkreślono też, że specyfikę tego podejścia tworzy działanie - spójne i na czas, na podstawie odpowiednich zdolności wojskowych i przy trwałym poparciu opinii publicznej. Właśnie na ten ostatni aspekt, tj. na konieczność solidnego legitymizowania międzynarodowych działań UE jako warunku ich powodzenia, zwrócono baczną uwagę: „Podstawowe znaczenie ma utrzymywanie wsparcia publicznego dla naszego zaangażowania na świecie. W nowoczesnych demokracjach, w których media i opinia publiczna odgrywają kluczową rolę w kształtowaniu polityki, poparcie społeczne jest niezbędne dla utrzymania naszego zaangażowania za granicą. Rozmieszczamy policję, ekspertów prawnych i żołnierzy w strefach niestabilnych na całym świecie. Na rządach, parlamentach i instytucjach UE ciąży obowiązek przekazywania informacji na temat tego, jak działania te przyczyniają się do bezpieczeństwa w kraju"

Oczywiście wspomniane tu właściwości europejskiej polityki bezpieczeństwa są dość ogólnikowe. Widać, że autorzy tego typu sformułowań unikali celowo uchwycenia istoty rzeczy ${ }^{6}$. Nasuwa się kilka pytań. Po pierwsze, czy działania na rzecz ukształtowania ESDP oddziaływują modyfikująco na narodowe tradycje polityki zagranicznej i bezpieczeństwa w kierunku wytworzenia się jakiegoś wspólnego mianownika? Po drugie, czy to jednak nie narodowe kultury strategiczne, wnosząc własne wiano do ESDP, wpływają w jakiś ograniczający sposób na aktywność UE w ramach ESDP? Sądzić bowiem można, że ten właśnie czynnik jest częściowo odpowiedzialny za - mimo wszystko - nadal niezadowalające postępy w kształtowaniu ESDP w dziesięć lat po jej zainicjowaniu przez UE na szczytach w Kolonii i Helsinkach. Jedna z ostatnich poważnych analiz dorobku ESDP zwracała uwagę na niekorzystną rolę narodowych kultur strategicznych, jako jedną z przyczyn nie sprzyjających realizacji przez UE operacji militarnych ${ }^{7}$.

Celem tego artykułu nie jest jednak kompleksowa analiza, jaki wpływ narodowe kultury strategiczne rzeczywiście wywierają na postępy w tworzeniu ESDP jako skutecznego narzędzia kształtowania przez UE stabilnego środowiska międzynarodowego, ile raczej analiza porównawcza narodowych kultur strategicznych państw członkowskich na podstawie kilku kryteriów. Innymi słowy, chodzi tutaj przede wszystkim o określenie - w przybliżeniu - stopnia spójności tych kultur, ale i refleksję, czy rzeczywiście ideowe różnice w podejściu do sfer bezpieczeństwa stanowią przeszkodę dla wykształcenia się bardziej ogólnej, uniwersalnej europejskiej kultury strategicznej.

$\mathrm{Na}$ potrzeby tego artykułu przedmiotem porównania uczyniono Niemcy, Francję i Wielką Brytanię. Trzy największe mocarstwa unijne mają nie tylko największy potencjał demograficzny, ekonomiczny, ale i wojskowy, w tej sferze ich wydatki w kategoriach absolutnych są najwyższe wśród państw członkowskich. Ponadto to trzy mocarstwa

5 Ibidem.

${ }^{6}$ Chodziło nie tylko o warunki militarnego angażowania się UE, lecz także o brak wyjaśnienia, w jakim priorytetowym zasięgu geograficznym UE winna podejmować swoje misje. Por. R. Kempin, M. Overhaus, Kein großer Spring in der Entwicklung der ESVP, „SWP-Aktuell”, 1, Januar 2009, s. 2.

7 D.C.F. Daniel, P. Taft, S. Wiharta (eds.), Peace Operations: Trends, Progress and Prospects, „European Security Review”, No. 44, December 2008, s. 4. 
były motorem powołania ESDP w 1999 r. po zwrocie w polityce brytyjskiej i pod wpływem wojny o Kosowo, a potem miały najwięcej do powiedzenia w sprawie jej dalszego rozwoju, kiedy po sporach wokół kryzysu irackiego zgodziły się na kompromisowy zapis w Traktacie Konstytucyjnym i przyspieszenie tworzenia grup bojowych w 2004 r. Trzeba zauważyć, że postępy te były możliwe dzięki trzem państwom, choć ich kierownicza rola nie zawsze miała pełne poparcie innych partnerów. Tak więc solidne i trwałe porozumienie między tymi trzema najważniejszymi aktorami jest przesłanką powodzenia projektu integracji w dziedzinie bezpieczeństwa. Na pewno zależy ono od ich zdolności do harmonizowania interesów bezpieczeństwa i narodowych kultur strategicznych. Ponadto tylko dzięki zbliżeniu między Niemcami, Francją i Wielką Brytanią projekt ten może stać się atrakcyjny dla pozostałych państw unijnych, a więc zyskać szerszą unijną legitymację i tym samym poszerzyć podwaliny pod europejską kulturę strategiczną.

Bez wątpienia ESDP odzwierciedla preferencje europejskie; jest sprawą dość oczywistą i powszechnie podkreślaną, że instytucja ta zachowa dominujący cywilny charakter, chociaż nie zrezygnuje z projekcji siły militarnej. Dwa te aspekty przejawiają się w niejednakowych proporcjach w różnych narodowych kulturach strategicznych. Oczywiście przyszła europejska kultura strategiczna będzie je odzwierciedlać i będzie stanowić ich mieszankę. Idzie więc o to, jak wyważyć znaczenie obu tych aspektów, o zaakceptowanie przez państwa członkowskie odpowiedniej proporcji pomiędzy nimi, aby ESDP mogła wspierać się na trwałym konsensie. Ujmując rzecz bardziej górnolotnie, wbrew temu, co twierdził Robert Kagan o „Europejczykach”, iż wydaje im się, że zamieszkują Kantowski świat „wiecznego pokoju”, świat wolny od wojen i przemocy ${ }^{8}$, bez wątpienia wiele jest w unijnej Europie miejsca, dla tych, którzy pojmują świat w kategoriach bardziej ,,archaicznych”, podkreślają aktualność Hobbesowskiej wizji świata anarchicznego, gdzie siła militarna odgrywa nadal żywotną rolę jako narzędzie agresywnej dyplomacji, i są przeciwni zwolennikom UE jako mocarstwa cywilnego uprzywilejowującego rozwiązania niemilitarne.

Jak w takim razie pomierzyć narodowe tradycje, by oszacować ich możliwy wkład do unijnej kultury strategicznej? Można wyznaczyć trzy kryteria.

Pierwsze dotyczy podstawowego sensu polityki bezpieczeństwa po zakończeniu zimnej wojny, tj. ewolucji od koncepcji bezpieczeństwa zogniskowanej na obronie terytorialnej i sojuszniczej w kierunku koncepcji tzw. poszerzonego bezpieczeństwa i łączącej się z nią roli UE jako eksportera bezpieczeństwa i stabilizacji, podejmującego aktywnie nowe wyzwania i zwalczającego nowe zagrożenia w środowisku zewnętrznym, aby zapobiegać ,importowi” destabilizacji.

Drugie pokrewne kryterium nawiązuje do zmiany sensu użycia siły militarnej po zakończeniu zimnej wojny i jej miejsca w ramach koncepcji poszerzonego bezpieczeństwa. Tutaj istotne jest określenie, jakie pociagga to za sobą konsekwencje w organizacji sił zbrojnych danego państwa i relacji cywilno-wojskowych?

Trzecie kryterium odnoszące się do problemu będącego również w pewnej mierze implikacją zakończenia zimnej wojny, adresuje kwestię rekonfiguracji sił w zachodnim sojuszu i wzajemną relację pomiędzy UE a NATO.

8 R. Kagan, Potega i raj. Ameryka i Europa w nowym porzq̨dku świata, Warszawa 2003. 
Oczywiście, aby odpowiedzieć na postawione tutaj pytania, należałoby przeprowadzić kompleksową, szeroko zakrojoną analizę dokumentów wytworzonych przez organa egzekutywy i parlamenty krajowe, jak i przeprowadzić stosowną analizę dyskursu politycznego. Na potrzeby tego krótkiego opracowania posłużono się metodą, którą można określić jako reprezentatywną. Analizie pod kątem trzech wspomnianych kryteriów, poddano najnowsze podstawowe dokumenty polityki bezpieczeństwa trzech państw (we Francji i Niemczech obiegowo określane jako tzw. białe księgi), które są przeznaczone do eksplikacji strategicznych celów i kodyfikowania reguł działania w dziedzinie bezpieczeństwa narodowego. Ponadto, co bardzo ważne, ich opracowanie łączy się z przełomowymi fazami przemian ich polityk bezpieczeństwa po zakończeniu zimnej wojny, kiedy Francja dokonywała reorientacji i starała się o powrót do wojskowych struktur Sojuszu Północnoatlantyckiego, a Niemcy dążyli do racjonalizacji nastawienia do użycia siły militarnej i przygotowywali Bundeswehrę do udziału w operacjach także bojowych ${ }^{9}$. Należy zatem uznać, że w dużym stopniu odzwierciedlają one narodowe kultury strategiczne na krytycznym etapie ich ewolucji. Są to dokumenty wytworzone przez władzę wykonawczą i oddają jej punkt widzenia, jednak ich autorzy kierowali się zasadą demokratycznej partycypacji, prowadząc mniej czy bardziej szerokie konsultacje polityczne nad tezami ${ }^{10}$. Natomiast w europejskim, unijnym kontekście trzeba je traktować z jednej strony jako swoistą odpowiedź na publikację Europejskiej Strategii Bezpieczeństwa w 2003 r., a z drugiej jako być może wstępny krok przygotowawczy do wypracowania stosownej europejskiej białej księgi bezpieczeństwa, która byłaby konkretną koncepcyjną implementacją rekomendacji Europejskiej Strategii Bezpieczeństwa. Można również spodziewać się, że z uwagi na swój programowy charakter dokumenty będą zawierać szereg ogólnych, uniwersalnych sformułowań, a więc, że będą cechować je podobieństwa, a obok tego znajdzie się miejsce dla uwydatnienia narodowej specyfiki. Faktycznie już przy pobieżnej nawet analizie widoczne są wspólne elementy.

\section{Koncepcja „poszerzonego bezpieczeństwa”: nowe zagrożenia i eksport stabilizacji}

W początkowych rozdziałach trzy dokumenty zajmują się problematyką wyzwań i zagrożeń bezpieczeństwa. Stosownie do obowiązującej po zimnej wojnie definicji „poszerzonego bezpieczeństwa” i podobnie jak w Europejskiej Strategii Bezpieczeństwa zostały one ujęte bardzo szeroko, przy czym najobszerniej zaprezentowano je we francuskiej Białej Księdze. Wspólne jest to, że priorytetowo potraktowano te same za-

9 Weißbuch 2006 zur Sicherheitspolitik Deutschlands und zur Zukunft der Bundeswehr, (hrsg.) Bundesministerium der Verteidigung 2006 (WB); The National Security Strategy of the United Kingdom, (ed.) Cabinet Office 2008 (NSS); Le Livre Blanc sur la Défense et la Sécurité nationale, Ministére de la Défense 2008 (LB).

10 D. Fiott, The French White Paper on Defence and National Security: Peacebuilding, NATO, Nuclear Weapons and Space, „European Security Review”, No. 40, September 2008, s. 5; M. Overhaus, Germany's New White Paper on Security Policy: Solid Basis for a Needed Debate, „Opinion Editorial", No. 32, October 26, 2006. 
grożenia: terroryzm międzynarodowy, rozprzestrzenianie broni masowego rażenia, problem tzw. państw upadłych, konflikty regionalne i przestępczość międzynarodowa. $\mathrm{Na}$ dalszym miejscu znalazły się określane jako główne wyzwania, m.in. zmiana klimatu, zagrożenia dla środowiska naturalnego, bezpieczeństwo energetyczne, nędza i ubóstwo, społeczne nierówności. Jednak nie zostały one wyraźnie zhierarchizowane. Znalazły się tutaj też specyficzne narodowe akcenty. I tak zarówno francuska Livre Blanc jak i brytyjska National Security Strategy odważniej niż niemiecki Weißbuch odnoszą się do klasycznych zagrożeń, upatrując ich w związku ze wzrostem potencjału ekonomicznego i demograficznego Indii i Chin, ich wydatkami na zbrojenia, jak i w zależności energetycznej od tych mocarstw i Rosji ( $L B$, s. 21, 25, 33; NSS, s. 18-19, 30), czy samymi wielkomocarstwowymi aspiracjami Rosji $(L B$, s. 37$)$. W uzupełnieniu do tego należy wspomnieć, że trzy dokumenty oczywiście nie pomijają klasycznego podstawowego celu polityki bezpieczeństwa w ogóle, jakim jest zachowanie suwerenności terytorialnej państwa i ochrona jego obywateli. Jednak i tutaj pojawia się pewna różnica o historycznej proweniencji, wynikającą z kolonialnej przeszłości Wielkiej Brytanii i Francji; zarówno Livre Blanc jak i National Security Strategy podkreślają, że ochrona dotyczy także obszarów zamorskich, jak i żyjących za granicą własnych obywateli, co implikuje, że interesy bezpieczeństwa obu mocarstw ulokowane są także poza kontynentem europejskim, mają zasięg prawie globalny, przejawiający się w stacjonowaniu sił zbrojnych w różnych częściach świata. Trzy dokumenty różnorako ujmuja geopolityczne priorytety. Weißbuch wylicza całą ich paletę - od Rosji, Zakaukazia, Bałkanów, Izraela, Bliskiego Wschodu, mocarstw azjatyckich, strefy subsaharyjskiej aż po rejon Morza Karaibskiego (WB, s. 55-58), co każe wattpić, jaka jest jakość przywiązywanych do nich interesów bezpieczeństwa. Można przypuszczać, że mają one rozmaite konotacje, tzn. że RFN jest niekiedy zainteresowana nimi w sensie militarnym, a przeważnie w sensie polityki rozwoju, ograniczania nędzy i ubóstwa, walki z głodem, propagowania wartości demokratycznych. Dla odmiany brytyjskie geopolityczne priorytety bezpieczeństwa są widziane przez pryzmat militarny; dotyczą przede wszystkim tradycyjnych brytyjskich stref wpływów i obszarów, na których Brytyjczycy są zaangażowani militarnie: Afganistan, Pakistan, Bliski Wschód, części Afryki (NSS, s. 40). Ogólnikowością charakteryzuje się Livre Blanc, gdzie jako najważniejszy obszar traktuje się oś od Atlantyku do Oceanu Indyjskiego, dalej Afrykę subsaharyjską, Europę Wschodnią z Bałkanami i Rosją, a na końcu Azję (LB, s. 43-49).

Również w sferze aksjologii można zaobserwować podobieństwa i różnice pomiędzy narodowymi strategiami. Polityka bezpieczeństwa i polityka obronna - w świetle trzech dokumentów - powinna zasadzać się na uznanych wartościach, reprezentowanych przez UE. Ich katalog sformułowano podobnie: są to prawa człowieka i praworządności na szczeblu międzynarodowym. $Z$ poszanowania dla tych wartości wywodzą trzy strategie powołanie do uczestniczenia w międzynarodowym zarządzaniu kryzysami (z użyciem siły włącznie) w oparciu o zasady nowoczesnej koncepcji ochrony i szerzenia wartości pod nazwą responsibility to protect, która implikuje prawo do interwencji, kiedy władze państwa nie są w stanie chronić swojej ludności od ludobójstwa, przestępstw wojennych, czystek etnicznych i zbrodni przeciw ludzkości. Wydaje się, że najpełniejsze konsekwencje z niedostatków zachodniej polityki wobec zagrożeń terroryzmem po 11 września wyciagnięto w niemieckiej białej księdze, gdzie zwrócono 
uwagę na ich korzenie, czyli na związki między procesami globalizacji a narastaniem zagrożeń. Koncepcja tzw. powiązanego bezpieczeństwa (vernetzte Sicherheit) kierując się pojęciem rozszerzonego bezpieczeństwa postuluje między innymi współpracę pomiędzy różnymi odpowiedzialnymi za bezpieczeństwo agendami i urzędami zarówno w sferze militarnej, jak i cywilnej (połączenie aktywności militarnej z działaniami na rzecz kompleksowej polityki rozwoju, albo inaczej szerzenia tzw. dobrych rządów). Dokument francuski preferuje kwestię użycia siły militarnej i ulepszania zdolności militarnych i pozostawia mniej miejsca dla cywilnych aspektów operacji międzynarodowych, dla integralnego traktowania obu wymiarów eksportu bezpieczeństwa, cywilnego i wojskowego. Podkreślono tutaj, że wojsko nie może zastąpić ani cywilnego planowania operacji, ani wytrenowanego personelu cywilnego i zadeklarowano tworzenie i szkolenie odpowiednich sił cywilnych jak i struktur zarówno na szczeblu narodowym, jak i unijnym (European Crisis Management Training Centre, specjalny dyrektoriat cywilno-wojskowy w instytucjach UE) ${ }^{11}$.

\section{Warunki użycia siły militarnej przez trzy mocarstwa}

Wszystkie trzy dokumenty ukazują, że siły zbrojne mają za zadanie realizowanie prawa do samoobrony, do obrony zbiorowej w sojuszniczych ramach, a co ważniejsze w kontekście koncepcji „rozszerzonego bezpieczeństwa” zadanie uczestniczenia w wielostronnych operacjach militarnych na rzecz opanowania konfliktu, również w tych, które mają bojowy charakter. Chociaż wszystkie zgodnie zaznaczają, że operacje takie mają być realizowane pod auspicjami ONZ, w ramach NATO czy UE, to Francja i Wielka Brytania - inaczej niż Niemcy - zastrzegają sobie możliwość prowadzenia takich operacji militarnych także samodzielnie - poza wspomnianymi strukturami (NSS, s. 7, 9; LB, s. 74).

Co najistotniejsze, trzy mocarstwa deklarują, że użycie siły militarnej na rzecz opanowywania konfliktów winno następować na zasadzie ultima ratio, czyli ostatecznego środka ( $L B$, s. 69). Takie formalne porównanie nie może jednak mylić, iż w ramach koncepcji poszerzonego bezpieczeństwa i afirmowanej roli UE jako ,eksportera bezpieczeństwa", kierującej się zasadą responsibility to protect, trzy mocarstwa cechuje podobne nastawienie do użycia siły militarnej.

W rzeczywistości zachowanie Niemiec różni się od podejścia Francji i Wielkiej Brytanii. Dla Berlina decyzja o delegowaniu Bundeswehry do sojuszniczej operacji militarnej obciążona jest zastrzeżeniami natury historycznej, specyficznym sceptycyzmem wobec użycia siły militarnej i wyraźną preferencją dla wspomnianej koncepcji kompleksowego kształtowania bezpieczeństwa. Widać to w Białej Księdze, ponieważ, jeśli poświęca się tu sporo miejsca na omówienie koncepcji zapobiegania kryzysom, rozwiązywania konfliktów, to w sprawach ewentualnego bojowego użycia siły militarnej w ramach crisis management, czego sojusznicy domagają się od RFN najbardziej,

11 Widoczny jest tu pewien dysonans pomiędzy deklarowaną przez Francję rolą UE jako ważnego gracza w zakresie crisis management a mimo wszystko słabym podkreśleniem cywilnego wymiaru unijnych operacji. Por. D. Fiott, op. cit., s. 6-7. 
wypada deficytowo. Generalnie w Niemczech przemiana filozofii bezpieczeństwa po zakończeniu zimnej wojny odbywała się, w porównaniu do Francji i Wielkiej Brytanii, znacznie wolniej i obfitowała w liczne przeszkody, także natury finansowej. Łączność z wcześniejszą tradycją widoczna jest jeszcze w mniejszej czy większej skali w zakresie organizacji sił zbrojnych, relacji cywilno-wojskowych i specyficznego systemu decyzyjnego. Od 1994 r. Bundestag partycypuje w sposób konstytutywny w decyzjach egzekutywy o udziale Bundeswehry w operacjach zagranicznych, a szczegóły tego reguluje specjalna ustawa (o tzw. współudziale parlamentu) z 2005 r., której sens należy odczytywać w kontekście tradycyjnej niemieckiej kultury powściagliwości nacechowanej ostrożnością wobec użycia siły militarnej ${ }^{12}$. $Z$ drugiej strony i w tej mierze zauważyć trzeba też pewne dostosowania na podobieństwo niemieckiego wzorca w Wielkiej Brytanii i Francji. Bowiem udział w operacjach sojuszniczych ostatnich lat (w wojnie w Iraku, w siłach ISAF w Afganistanie) przyniósł znaczące skutki zwrotne dla strukturalnych przemian polityki bezpieczeństwa tych dwóch mocarstw. Zarówno Livre Blanc jak i National Security Strategy podkreślają teraz - śladem niemieckiej strategii - rosnące znaczenie parlamentarnej legitymacji udziału w takich operacjach. Bardziej demokratyczne umocowanie decyzji egzekutywy ma służyć przekonywaniu opinii publicznej do celowości coraz częstszego delegowania własnych wojsk do operacji zagranicznych jako skutecznego remedium na zagrożenia pozimnowojenne. Premier Gordon Brown potwierdził tryb wprowadzony w 2003 r. przez swojego poprzednika premiera T. Blaira o dopuszczeniu parlamentu do głosowania nad udziałem sił brytyjskich w wojnie przeciw Irakowi. Również we Francji prezydent Nicolas Sarkozy zainspirował zmianę konstytucji w kierunku zapewnienia parlamentowi współudziału przy decyzjach o operacjach wojskowych trwających dłużej niż cztery miesiące ${ }^{13}$.

Właśnie potrzeba sprostania nowym wyzwaniom wymaga kontynuowania reform wojskowych, które mają na celu zwiększenie operacyjnej skuteczności sił zbrojnych. W dokumentach znajduje to wyraz albo w ogólnikowych frazach (NSS mówi o expeditionary operations, wymagających sprawnych operacyjnie i elastycznych sił; NSS, s. 38), albo jest ujmowane stosunkowo konkretnie. Livre Blanc określa zadania operacyjne wyraźnie jako „interweniowanie” (Intervenir) i przewiduje dla ich realizacji siły operacyjne w wysokości 88 tysięcy, z czego 30 tysięcy żołnierzy, ma być dyslokowanych na okres od pół do jednego roku i na dystans do 8 tysięcy kilometrów ( $L B$, s. 199, 211). Weißbuch nazywa kierunek przekształceń Bundeswehry jako „ukierunkowanie operacyjne" (Einsatzorientierung) i kategoryzuje w tym celu dwa rodzaje sił, które odpowiadają dwóm rodzajom operacji: siły interwencyjne (Eingreifkräfte) są przeznaczone do operacji o tzw. wysokiej intensywności, tzn. zakładającej użycie broni, a siły stabilizacyjne (Stabilisierungskräfte) do operacji o niskiej lub średniej intensywności (WB, s. 94). Generalnie wszystkie trzy strategie zwracają uwagę, że siły zbrojne muszą

12 Zob. szerzej K. Malinowski, Mocarstwo cywilne a problem użycia sity. Uprawnienia Bundestagu w zakresie delegowania Bundeswehry do udziału w operacjach zagranicznych, w: K. Bachmann, P. Buras (red.), Niemcy jako państwo cywilne. Studia nad niemiecka polityka zagraniczna, Wrocław 2006

13 A. Jonas, M. Klemm, N. v. Ondarza, Auf dem Weg zu einer europäischen strategischen Kultur?, „SOWI.NEWS. Newsletter des Sozialwissenschaftlichen Instituts der Bundeswehr”, H. 1/2009, s. 8. 
być gotowe do udziału w operacjach realizujących całe spektrum zadań (od stabilizacyjnych po bojowe). Tendencja do rozwijania mniejszych, elastycznych oddziałów, zdolnych do szybkiego wyekspediowania i na dłuższy dystans geograficzny, obejmujących szeroką gamę zdolności, wynika z deklarowanego przez trzy mocarstwa zainteresowania projekcją siły militarnej. Jednak Paryż i Berlin oraz Londyn z drugiej strony wyprowadzają z tego różne konkluzje. Ulepszanie zdolności wojskowych w ramach ESDP ma dokonywać się poprzez wspólną politykę zbrojeniową w ramach Europejskiej Agencji Obrony. Francji i Niemcom zależy na tworzeniu europejskiej polityki zbrojeniowej, aby wzmacniać ESDP ( $L B$, s. 264; $W B$, s. 74). Wielka Brytania natomiast jest sceptyczna, akcentując wysokie koszty wspólnych projektów i opowiada się za rynkowymi rozwiązaniami w tej mierze (NSS, s. 46).

Do specyfiki poszerzonego bezpieczeństwa należy konstatacja o zacieraniu się różnic między klasycznym bezpieczeństwem zewnętrznym odnoszącym się do zagrożeń stwarzanych przez państwa nawzajem oraz bezpieczeństwem wewnętrznym, lub też o narastających powiązaniach między obu aspektami bezpieczeństwa ( $W B$, s. $64 ; L B$, s. 57; NSS, s. 8). Implikuje to potrzebę koordynowania działań pomiędzy sferą wojskową i cywilną na zasadzie współpracy ponadresortowej, przy czym siły wojskowe i cywilne powinny się uzupełniać. Dotyczy to oczywiście przede wszystkim operacji zewnętrznych i współpracy sił zbrojnych z aktorami cywilnymi na rzecz realizacji ich celów.

Również i w tej sferze o ewidentnej dominacji urzędu prezydenta we Francji i w mniejszym stopniu premiera w Wielkiej Brytanii może świadczyć istnienie ponadresortowych ciał koordynacyjnych (we Francji - Rada ds. Obrony i Bezpieczeństwa Narodowego, $\mathrm{z}$ udziałem premiera, ministrów spraw zagranicznych, wewnętrznych, obrony, finansów i gospodarki; $L B$, s. 252; w Wielkiej Brytanii - Komitetu bezpieczeństwa narodowego, stosunków międzynarodowych i rozwoju, NSS, s. 5, 58). W Niemczech natomiast $\mathrm{w}$ okresie rządów wielkiej koalicji brak było porozumienia pomiędzy chadecją i socjaldemokracją w sprawie dowartościowania istniejącej Federalnej Rady Bezpieczeństwa, z powodu obaw SPD, iż ewentualnie doprowadzi to do wzmocnienia urzędu kanclerskiego, kanclerz Angeli Merkel i chadecji ${ }^{14}$.

Utrzymywanie się związków z wcześniejszą tradycją w zakresie organizacji sił zbrojnych poświadcza zachowanie zasady obrony terytorialnej i stosownie do tego sporego, trzonowego komponentu sił głównych. W bliskiej łączności z tym należy widzieć dążenie do zachowania obowiązku powszechnej obrony (Wehrpflicht), który jest jednoznacznie postrzegany jako element specyficznej kultury bezpieczeństwa, symbolizujący demokratyczną naturę Bundeswehry, armii obywatelskiej, łącznika sił zbrojnych ze społeczeństwem.

Jeśli Francja i Wielka Brytania są przywiązane do obrony terytorialnej, to wynika to z klasycznych przesłanek bezpieczeństwa. W przypadku Niemiec Weißbuch potwierdza wyraźnie, że klasyczna obrona terytorialna i sojusznicza stanowią centralne zadanie Bundeswehry. Wynika to głównie z ich powojennej tożsamości, dążenia do podkreślania wiarygodności sojuszniczej Niemiec i zaprzeczenia militarystycznej spuścizny

14 An 'Americanization' of German Foreign Policy?, ,,Spiegel Online International”, 5.05.2008. 
historycznej. W National Security Strategy i Livre Blanc potwierdzono wyraźnie sens obrony terytorialnej i zachowania silnych zdolności w dziedzinie broni konwencjonalnej oraz zachowanie zasady odstraszania nuklearnego w celu ochrony przed ewentualnymi zagrożeniami stwarzanymi przez inne państwa i ze względu na to, że nie można wykluczyć klasycznej wojny między państwami. Przede wszystkim jednak zachowanie doktryny odstraszania nuklearnego i nuklearnego potencjału w przypadku Francji i Wielkiej Brytanii trzeba uważać po prostu za wykładnik utrzymywania i podnoszenia na arenie międzynarodowej prestiżowego statusu mocarstwa nuklearnego. Tego atrybutu mocarstwowości Niemcy są pozbawione. Generalnie jeśli nawet we wszystkich trzech dokumentach deklaruje się zasadę obrony terytorialnej, to dostrzega się kolosalne wyzwania, jakie wynikają z konieczności godzenia reformowania i modernizowania obrony terytorialnej z priorytetowo traktowanymi operacjami zagranicznymi, a przede wszystkim zagrożenia nowego typu (NSS, s. 43 i n.; $L B$, s. 64; $W B$, s. 62). Jednak mimo potrzeby pragmatycznego podejścia do reformy sił zbrojnych, RFN do jesieni $2009 \mathrm{r}$. nie rezygnowała z obowiązku powszechnej służby wojskowej, choć ogranicza udział tej kategorii żołnierzy w strukturze personalnej Bundeswehry.

\section{ESDP i stosunki transatlantyckie}

Tradycyjnie najpoważniejsze znaczenie dla kształtowania się ESDP mają relacje w trójkącie Francja-Wielka Brytania-Niemcy, przy czym najsilniejsze kontrowersje występują między dwoma mocarstwami nuklearnymi. Livre Blanc zapowiadała kopernikański zwrot w polityce Francji, na miarę tego, który nastapił dziesięć lat wcześniej w polityce Wielkiej Brytanii wobec idei europejskiej polityki bezpieczeństwa pod egidą UE. W dokumencie tym opowiedziano się za odnowieniem stosunków Francji z Sojuszem poprzez powrót do jego struktur militarnych. Krok ten był nadzwyczaj pragmatyczny i świadczył, że pod przywództwem N. Sarkozy'ego Francja zaczęła traktować ESDP nie jako środek do podważania spójności NATO, lecz jako inicjatywę komplementarną, a także do polepszenia stosunków ze Stanami Zjednoczonymi. Zwrot ku NATO miał rozproszyć wątpliwości USA oraz transatlantycko nastawionych europejskich partnerów i tym samym zdynamizować rozwój ESDP, a docelowo doprowadzić do nowej równowagi między UE a USA. Dano wyraz pragnieniu zachowania dla Francji pełnej autonomii od USA w sferze obrony nuklearnej ( $L B$, s. 107 i n.). Francuscy decydenci upatrują w UE przyszłego poważnego aktora międzynarodowego w sferze bezpieczeństwa, także pod postacią unii obronnej ( $L B$, s. 81-98). Choć łączy Francję i Wielką Brytanię wola działania w sprawach bezpieczeństwa i geostrategiczny zasięg interesów, to nie do przeoczenia jest jednak podstawowa rozbieżność między nimi. Można o niej wnioskować na podstawie zapisów National Security Strategy w sprawie udziału Wielkiej Brytanii w operacjach unijnych. Przewidują one, iż UE może być płaszczyzną działania tylko dla realizowania operacji cywilnych albo operacji służących stabilizacji na obszarach pokonfliktowych (NSS, s. 9). W przypadku operacji militarnych wyraźne jest faworyzowanie NATO lub koalicji ze Stanami Zjednoczonymi, przy czym UE nawet nie została wspomniana. Również zastrzeżenie opcji w razie potrzeby samodzielnego działania militarnego (tj. poza strukturami instytucjonalnymi) 
dodatkowo stanowi przyczynę utrudniającą współdziałanie w ramach UE, jak pokazało zachowanie Wielkiej Brytanii w kryzysie irackim. Natomiast Weißbuch deklaruje odgrywanie przez Niemcy roli raczej dośrodkowej, sprzyjającej współpracy, roli pośrednika między Francją i Wielką Brytanią (WB, s. 49). Zadziwiające, że nie znalazło się tutaj żadne odniesienie do przyszłości NATO, tj. do tego, jakie cele winien on wypełniać i w jakim kierunku się rozwijać, choć to co łączy Niemcy z podejściem Wielkiej Brytanii to uznanie, iż NATO jest ,,podstawą niemieckiej polityki bezpieczeństwa i obrony”, w czym należy upatrywać znaczącego odstępstwa od linii kanclerza G. Schrödera, który sygnalizował zainteresowanie rozwijaniem ESDP w kierunku gaullistowskim.

\section{Wnioski}

Wprawdzie trzy mocarstwa mają zbliżone rozumienie ryzyk i zagrożeń, deklarują mniej czy bardziej podobne podejście aksjologiczne i są gotowe do eksportu stabilizacji włącznie z zaangażowaniem militarnym, to jednak różnią się pod pewnymi względami, które mogą utrudniać ich współpracę w ramach ESDP. Francję i Wielką Brytanię wyróżniają zarówno deklarowane przywiązanie do odstraszania nuklearnego, jak i zastrzegana kompetencja do prowadzenia samodzielnych operacji, a nie tylko pod egida ONZ, i poza ramami sojuszniczymi, także z uwagi na zamorskie terytoria i ochronę własnych obywateli, ale także zbliżone geopolityczne zainteresowania. Z drugiej strony chodzi tu przede wszystkim o większą ostrożność Niemiec wobec użycia siły militarnej, tj. udziału w operacjach bojowych i preferencję dla działań cywilnych. Natomiast Francja i Wielka Brytania są jednoznacznie skłonne do instrumentalnego traktowania sil zbrojnych i projekcji siły militarnej jako czynnika demonstrowania suwerenności i podnoszenia prestiżu. Niemcy cechuje wyraźnie niższa gotowość polityczna do posługiwania się siłami zbrojnymi jako instrumentem polityki zagranicznej (mimo że deklaruje to jednoznacznie Weißbuch). Tę różnicę potwierdzają także odmienne praktyki w zakresie decyzyjnym RFN, które w znacznie większym stopniu niż w przypadku Francji i Wielkiej Brytanii podkreślają rolę parlamentu i tym samym wewnątrzpolitycznej legitymizacji użycia siły militarnej. Druga istotna rozbieżność zarysowuje się nadal co do instytucjonalnych ram eksportu bezpieczeństwa przez trzy mocarstwa, tj. tego, czy i w jakim wymiarze powinno ono się odbywać w ramach UE czy NATO.

Mimo tych wyłaniających się ze strategicznych dokumentów niekompatybilności, należy dostrzec znaczące procesy adaptacyjne wśród trzech mocarstw, w największym nasileniu w przypadku Niemiec. Republika Federalna przełamała historyczną awersję wobec użycia siły militarnej, podejmując stopniowo udział w sojuszniczych operacjach militarnych, także tych, które miały wymiar bojowy, jak w Afganistanie (operacja „Enduring Freedom” i ISAF). Natomiast zarówno Francja, jak i Wielka Brytania, w związku z nasilającym się zaangażowaniem zagranicznym, poczyniły pewien krok na rzecz rozszerzenia legitymizacji politycznej dla decyzji o użyciu siły. Ponadto reorientację Francji w sprawie NATO trzeba ocenić jako konstruktywną, ponieważ sprzyjającą zbliżeniu między nurtem europejskim a euroatlantyckim w ramach UE. 
Kluczowe dla rozwijania europejskiej kultury strategicznej będzie wypracowanie przez trzy mocarstwa bardziej spójnego, a zarazem kompleksowego strategicznego podejścia do eksportu stabilności przez UE, a tutaj określenie pewnych narodowych preferencji i pewnej równowagi między komponentem cywilnym a militarnym. Sądząc po całej gamie operacji w ramach ESDP, wśród których przeważają te o charakterze pozawojskowym, wykształcająca się kultura strategiczna UE, a tym samym jej instrument w postaci ESDP ma szansę uzyskać nowoczesny profil, skoncentrowany głównie na stabilizacyjnym, cywilizacyjnym zaangażowaniu i abstrahujący od operacyjnego użycia siły militarnej, a więc odmienny od profilu, jaki wykształca się w ramach Sojuszu Północnoatlantyckiego prowadzącego działania bojowe w Afganistanie (ISAF).

Tak więc rozbudowa cywilnego profilu ESDP może sprzyjać upodobnianiu narodowych tradycji polityki zagranicznej i bezpieczeństwa poprzez włączanie wspólnych elementów do krajowych strategii bezpieczeństwa w postaci koncepcji uzasadniających cywilne zaangażowanie UE w ramach operacji stabilizacyjnych, rekonstrukcyjnych, tworzenia ładu na obszarach pokonfliktowych oraz operacji humanitarnych, jak pokazują to przykłady aktywności ESDP w Bośni, Kosowie, Macedonii, Kongu, Czadzie, Indonezji, Afganistanie. Chodzi tu także o wspomnianą rosnącą potrzebę wewnątrzpolitycznej legitymizacji zaangażowania militarnego.

$\mathrm{Z}$ drugiej strony jednak narodowe kultury strategiczne wpływają w ograniczający sposób na aktywność UE w ramach ESDP. Dzieje się to np. wtedy, kiedy utrzymująca się mimo wszystko ostrożność Republiki Federalnej Niemiec wobec użycia siły militarnej styka się z niechęcią Wielkiej Brytanii do realizowania operacji stricte militarnych w ramach ESDP w przekonaniu, iż ten rodzaj działań operacyjnych sił zbrojnych jest zastrzeżony dla współpracy w ramach NATO. Ta koincydencja umacnia mimowolnie cywilny profil „eksportu” stabilizacji przez UE. Paradoksalnie być może pozwoli to utrwalić komplementarny charakter rozwijania funkcji out of area między UE a NATO ${ }^{15}$. W związku z tym rodzi się jednak pytanie, jak pogodzić europejską kulture strategiczną kształtowaną pod egidą UE z implikacjami wynikającymi dla europejskich członków z członkostwa w NATO? Czy instytucja ESDP jest rzeczywiście jedynym mechanizmem generującym europejską kulturę strategiczną? Z pewnością bowiem NATO i sojusznicze wytyczne w dziedzinie ulepszania zdolności militarnych jako niezbędnego warunku sprostania współczesnym zagrożeniom, odgrywają równie ważną rolę w ujednolicaniu narodowych pryzmatów strategicznych. Mogłaby temu służyć szersza debata europejska z udziałem opinii publicznych zainteresowanych pogłębianiem integracji państw członkowskich. Można wyobrazić sobie, że jej celem powinno być nie tylko zbliżenie narodowych security communities, lecz także wypracowanie podstaw dla europejskiej Białej Księgi Bezpieczeństwa.

15 Jednak raport z implementacji z 2008 r. wskazywał na konieczność dalszych starań o rozwijanie tego profilu i zachęcał Sekretarza Generalnego/Wysokiego Reprezentanta do utworzenia pojedynczej struktury planowania cywilno-wojskowego dla misji ESDP. Ponadto konstatował, że formalne relacje między UE a NATO nie rozwinęły się i że potrzebna jest lepsza współpraca operacyjna pomiędzy nimi. Report by the EU High Representative..., s. 2, 11. 